\title{
Lipid profile and dietary habits in an elderly rural population in the southern Spain: the Sierra de Huelva study
}

\author{
By Francisco Martín, ${ }^{a}$ M. Luisa Escudero-Gilete ${ }^{\mathrm{b}}$ and Isabel M. Vicario ${ }^{\mathrm{b*}}$
}

\author{
${ }^{a}$ Clínica Medicentro Scientific assessor of DO Jamón de Huelva \\ ${ }^{b}$ Department of Food Science and Nutrition. Faculty of Pharmacy. University of Seville. \\ C/ P. García González s/n. 41012 Sevilla. Spain \\ ( ${ }^{\star}$ Corresponding author: vicario@us.es)
}

\section{RESUMEN}

Perfil lipídico y hábitos alimentarios en una población anciana rural del sur de España: el estudio de la Sierra de Huelva.

Hemos evaluado los lípidos séricos, la presión sistólica (SBP) y diastólica (DBP) en un grupo de ancianos no institucionalizados de más de 70 años que residen en una zona rural localizada en el sur de España, la Sierra de Huelva. 401 ancianos, 229 mujeres (F) and 179 hombres (M) con una edad media de 79,36 \pm 6,9 años, se incluyeron en este estudio observacional transversal. Los hábitos alimentarios fueron evaluados mediante una modificación del Mediterranean Diet Score MMDS) que incluyó a 11 grupos de alimentos. Se obtuvo una puntuación total que oscilaba entre 0-44. La concentración media de lípidos fue: colesterol total (TC) $193,8 \pm 23,1, M 195,2 \pm 25,7$ y F 192,7 $\pm 20,8(p=0,29)$; HDLc $60,3 \pm 7,6 \mathrm{mg} / \mathrm{dl}, \mathrm{M} \mathrm{58,0} \pm 8,0$ y F 60,5 $\pm 7,2$ ( $\mathrm{p}=$ $0,49) ; \mathrm{TC} / \mathrm{HDLC} 3,3 \pm 1,1 \mathrm{mg} / \mathrm{dl}, \mathrm{M} 3,4 \pm 1,2$ and $\mathrm{F} 3,3 \pm 1,1$ $\mathrm{mg} / \mathrm{dl}(\mathrm{p}=0,35) ;$ LDLc 127,3 $\pm 30,1 \mathrm{mg} / \mathrm{dl}, \mathrm{M} 129,0 \pm 32.9$ F 127,3 $\pm 30,1 \mathrm{mg} / \mathrm{dl}(\mathrm{p}=0,33) ; \mathrm{TG} 137,7 \pm 18,8, \mathrm{M} 138,8$ $\pm 19,4$ y $F 136,0 \pm 17,4(p=0,30)$. La prevalencia total de hipercolesterolemia (TC $\geq 200 \mathrm{mg} / \mathrm{dl}$ ) fue de $8,7 \%, F 7,9 \%$ y M 9,9\%; $10,7 \%$ de la población presentó niveles de LDLc $\geq 160 \mathrm{mg} / \mathrm{dl}$. La edad se correlacionó negativamente $(p$ $<0,05)$ con TC, LDLc, TG y SBP y positivamente con el HDLc. Según los datos de MMDS la adherencia a la Dieta Mediterranea fue del $60.6 \pm 6.9 \%$. El consumo de carne de cerdo se correlacionó negativamente con CT y LDLc, y positivamente con HDLc. EI MMDS se relacionó positivamente con la edad y negativamente con el valor de TG $(p<0,05)$. Serán necesarios más estudios para determinar el efecto que el consumo de productos del cerdo ibérico y el estilo de vida tienen sobre la menor incidencia de factores de riesgo cardiovascular y la mayor expectativa de vida de la población estudiada.

PALABRAS CLAVE: Anciano - Colesterol total - Enfermedad cardiovascular - Lípidos plasmáticos - Puntuación dietética.

\section{SUMMARY}

Lipid profile and dietary habits in an elderly rural population in the southern Spain: the Sierra de Huelva study.

We have assessed serum lipids, systolic (SBP) and diastolic (DBP) blood pressure in a healthy, free living population over 70 years old residing for more than 20 years in a rural area located in the southern Spain, the Sierra de
Huelva. 401 elderly, 229 women (F) and 179 men (M) mean age $79.36 \pm 6.9$ were included in this cross-sectional observational study. Dietary habits were assessed by means of a Modification of the Mediterranean Diet Score (MDDS), which comprised 11 components. A total score ranging from 0-44 was calculated. Mean concentration for lipids were: Total cholesterol (TC) $193.8 \pm 23.1, \mathrm{M} 195.2 \pm 25.7$ and $\mathrm{F}$ $192.7 \pm 20.8(p=0.29) ;$ HDLc $60.3 \pm 7.6 \mathrm{mg} / \mathrm{dl}, \mathrm{M} 60.0 \pm$ 8.0 and $F 60.5 \pm 7.2(p=0.49) ; T C / H D L c 3.3 \pm 1.1 \mathrm{mg} / \mathrm{dl}$, M $3.4 \pm 1.2$ and $F 3.3 \pm 1.1 \mathrm{mg} / \mathrm{dl}(p=0.35) ;$ LDLc $127.3 \pm$ $30.1 \mathrm{mg} / \mathrm{dl}, \mathrm{M} 129.0 \pm 32.9 \mathrm{~F} 126.0 \pm 27.8 \mathrm{mg} / \mathrm{dl}(\mathrm{p}=0.33) ;$ TG $137.7 \pm 18.3, \mathrm{M} 138.8 \pm 19.4$ and $\mathrm{F} 136 \pm 17.4(\mathrm{p}=$ 0.30 ). Global prevalence of hypercholesterolemia (TC $\geq 200$ $\mathrm{mg} / \mathrm{dl}$ ) was $8.7 \%, \mathrm{~F} 7.9 \%$ and $\mathrm{M} 9.9 \% ; 10.7 \%$ had LDLc $\geq 160$ $\mathrm{mg} / \mathrm{dl}$. In this study, age was negatively correlated $(p<0.05)$ with TC, LDLC, TG and SBP and positively with HDLc. Pig meat consumption was negatively correlated with $\mathrm{CT}$ and LDLc, and positively with HDLc. According to MMDS data, $60.6 \pm 6.9 \%$ of adherence to the Mediterranean diet was obtained. The MMDS was positively associated with age and negatively with TG $(p<0.05)$. Further studies are needed to establish the influence of local Iberian pig meat products consumption and life style on the lower incidence of risk factors for CVD and the higher life expectancy of the studied population.

KEY-WORDS: Cardiovascular disease - Diet score Elderly - Serum lipids - Total cholesterol.

\section{INTRODUCTION}

The leading cause of death in the industrialized countries is cardiovascular disease (CVD) which accounts for more than $45 \%$ of death in people over 65 years (Villar Álvarez et al., 2007). Spain is one of the European countries with the greatest proportion of elderly persons and some estimations indicate an increase in the percentage of subjects aged 60 years old from $19 \%$ currently to $40 \%$ in year 2050 (Tinker, 2002). Hypercholesterolemia is one of the most prevalent cardiovascular risk factors. The relations between dietary fats and serum lipids have been explored in intervention, epidemiological and observational studies (Lairon, 2007). Diets with high content of saturated fat increases total cholesterol (TC) and Low density lipoprotein-cholesterol (LDLC) levels, which are associated with a higher risk of CVD. Meanwhile, unsaturated fat consumption has a cholesterol-lowering effect that is associated with 
a reduced risk of cardiovascular disease (Mead et al., 2006).

The Mediterranean diet has long been associated with lower incidence of cardiovascular disease (CVD) (de Lorgeril, et al., 1999; Trichopoulou, 2006; Sofi et al., 2008). Since the definition given by Ancel Keys in the Seven Countries Study (Keys, 1980), to the food habits of some populations in the Mediterranean areas, many studies have been conducted to define this dietary pattern (Trichopoulou and Lagiou, 1997). Essential components in the Mediterranean diet are fresh fruit, vegetables, cereals, fish, moderate consumption of milk and dairy products, mostly in the form of cheese, low consumption of meat and meat products, and moderate quantities of alcohol during meals and olive oil as the only source of fat. However, dietary pattern may vary widely between coasts and inland (Contaldo et al., 2003). This dietary pattern has shown to be beneficial for all cause of cardiovascular mortality, lipid metabolism, blood pressure, and several different disease states such as endothelial dysfunction and overweight (Willet, 2006). However other aspects related with lifestyle should be considered, as the extensive physical activity, mainly related to work and outdoor leisure activities, which prevailed in these populations until the sixties. In recent years, this healthy lifestyle that favoured cardiovascular health has changed and the ongoing decline in mortality due to ischemic heart disease has slowed down (Bertomeu and Castillo, 2008).

Sierra de Huelva is a rural zone in the Southern Spain (Andalusia) with particular characteristics. It's situated at $420 \mathrm{~m}$ over the sea level and it is not well communicated with the main cities (Huelva and Seville). The traditional economic activity is related with the Iberian pig breeding and production of derived products. The Iberian pig (Sus Mediterraneus) production system is one of the few traditional ones which have survived due to the highly demanded characteristics of the derived drycured products. The animals are reared outdoor in the Mediterranean silvopastoral system (called "La Dehesa"), grazed on acorns (Quercus spp) and pasture. The resulting meat products not only have a high sensory quality but they also have a lipid profile characterized by a high content of oleic acid which represents over $55 \%$ of total fatty acids, for this reason, it is usually called a "walking olive tree", and it is consider a healthy food (Viera Alcaide, 2007). Some studies have shown that including acorn-fed Iberian ham in the diet of older adults has beneficial effects on some atherogenic risk factors as lipid profile, blood pressure and lipid peroxidation (García Rebollo et al., 1998; Mayoral et al., 2003).

The present study was aimed to make a general survey of the lipid profile, blood pressure and dietary habits in a group of free living healthy elderly individuals over 70 years old, residing in the rural area in southern Spain, Sierra de Huelva, to evaluate the influence of dietary habit on cardiovascular risk factors.

\section{MATERIALS AND METHODS}

\subsection{Subjects and dietary assessment}

Data presented here correspond to a crosssectional observational study of elderly free-living subjects, who resided in a rural area in the Sierra de Huelva (South of Spain) and Alentello (Portugal) for more than 20 years. They all lived in small towns with less than 800 habitants and they attended a Primary Health Care Centre. They were healthy and well nourished. The study group was made up of 401 elderly persons aged $>70$ years. 172 were men (7096 years) and 229 were women (70-98 years). Agegroups and sex distribution are shown in Table 1.

Dietary pattern was assessed by means of a modification of the Mediterranean diet score proposed by Panagiotakos et al. (2006). A food frequency questionnaire containing 11 items representative of the Mediterranean diet in this area (Table 2) was used. The questionnaire included consumption of Iberian pig meat and derived products and lamb meat as separate groups, since these are typical products in this area. The questionnaire was completed with the help of a trained dietician. Dietary questionnaire was based on servings/week consumption. For the consumption of items close to the Mediterranean pattern we assigned scores 0-4, when a participant reported no consumption, 1 serving/week, 2-3 servings/week, 46 servings week and daily, respectively. For the consumption of foods presumed to be away from this pattern we assigned the scores on a reverse scale. Then a total score ranging from 0 to 44 was calculated. Higher values of the modified Mediterranean diet score (MMDS) indicate greater adherence to the Mediterranean diet.

Table 1

Mean age of the studied population by sex and age group

\begin{tabular}{|c|c|c|c|c|c|c|}
\hline \multirow[b]{2}{*}{ Age group } & \multicolumn{3}{|c|}{ Female $\mathrm{n}=\mathbf{2 2 9}$} & \multicolumn{3}{|c|}{ Male = 172} \\
\hline & Mean $\pm \mathbf{s d}$ & $\mathbf{n}$ & $\%$ & Mean \pm sd & $\mathbf{n}$ & $\%$ \\
\hline $70-75(1)$ & $72.26 \pm 1.69$ & 62 & 15.5 & $72.47 \pm 1.64$ & 75 & 18.7 \\
\hline $76-80(2)$ & $77.30 \pm 1.18$ & 47 & 11.7 & $78.20 \pm 1.35$ & 61 & 15.2 \\
\hline $81-85(3)$ & $82.34 \pm 1.06$ & 32 & 8.0 & $83.30 \pm 1.20$ & 47 & 11.7 \\
\hline $86-90(4)$ & $87.55 \pm 1.31$ & 20 & 5.0 & $87.72 \pm 1.31$ & 25 & 6.2 \\
\hline $91-95(5)$ & $92.44 \pm 1.59$ & 9 & 2.2 & $93.50 \pm 1.41$ & 16 & 4.0 \\
\hline$>95(6)$ & $96.00 \pm 0.00$ & 2 & 0.3 & $98.00 \pm 1.22$ & 5 & 1.2 \\
\hline
\end{tabular}


Table 2

The dietary questionnaire employed for calculating the Modified Mediterranean Diet Score (MMDS) in the Sierra de Huelva study

\begin{tabular}{lccccc}
\hline & \multicolumn{5}{c}{ Frequency of consumption (servings/week) } \\
\cline { 2 - 6 } How often do you consume? & Never & $\mathbf{1}$ & $\mathbf{2 - 3}$ & $\mathbf{4 - 6}$ & Daily \\
\hline Cereals (bread, rice, pasta) & 0 & 1 & 2 & 3 & 4 \\
Fruits & 0 & 1 & 2 & 3 & 4 \\
Vegetables & 0 & 1 & 2 & 3 & 4 \\
Legumes & 0 & 1 & 2 & 3 & 4 \\
Fish & 0 & 1 & 2 & 3 & 4 \\
Pig meat & 4 & 3 & 2 & 1 & 0 \\
Poultry & 4 & 3 & 2 & 1 & 0 \\
Lamb-meat & 4 & 3 & 2 & 1 & 0 \\
Eggs & 4 & 3 & 2 & 1 & 0 \\
Full fat dairy products (Milk, Cheese) & 4 & 3 & 2 & 1 & 0 \\
Olive oil (cooking, salads) & 0 & 1 & 2 & 3 & 4 \\
\hline
\end{tabular}

\subsection{Laboratory determination}

Blood samples were taken at the Health Care Centre or their homes, under fasting conditions. Blood was obtained from an antecubital vein. Total serum cholesterol (TC), LDLc and HDLc, triglyceride levels were measured by enzymatic colorimetric methods with an Olympus AU 2700 autoanalyzer using reagents from Olympus Diagnostics, $\mathrm{GmbH}$ (Hamburg, Germany). Diastolic (DBP) and systolic blood (SBP) pressure were measured during the home visit or at the health care centre. A medical history was taken by a physician. For classification purposes the criteria's of the European Society of Hypertension (ESH) and of the European Society of Cardiology (ESC) (The Task Force for the Management of Arterial Hypertension of the European Society of Hypertension (ESH) and of the European Society of Cardiology (ESC, 2007) and those of the Spanish Society of Atherosclerosis (Sociedad Española de Aterosclerosis, 1994) were considered.

\subsection{Statistical analysis}

The study population was divided into groups by age. Variables are presented as mean values \pm standard deviation. Pearson's correlation coefficient was used to examine the association between categorical and continues variables. Significant differences between groups for the continue variables were computed by analysis of variance (ANOVA). All statistic calculations were performed by Statistica v. 6

\section{RESULTS AND DISCUSSION}

\subsection{Age, sex and serum lipids}

Of the 401 elderly people over 70 years included in the study, $43 \%$ were men and $57 \%$ were women (Table 1). The mean age was $79.36 \pm 6.87,79.90$ \pm 7.10 for $F$ and $78.62 \pm 6.52$ for $M(p=0.06)$.
Spain is one of the countries with the oldest population in Europe. Life expectancy at birth in Spain is 80.23 years ( 76.96 for $M$ and 83.48 for $F$ ) (Instituto Nacional de Estadítica, 2007). According to this, $23.25 \%$ of the elderly people included in this study were over the life-expectancy of the Spanish population ( $17 \%$ of $\mathrm{F}$ and $23.8 \%$ of $\mathrm{M}$ ), although it is even higher if we consider that life expectancy for the Andalusian population is slightly lower (76.35 for $\mathrm{M}$ and 82.56 years for $\mathrm{F}$ ).

Table 3 and 4 shows the mean values and standard deviation for the lipid profile and blood pressure in the studied population grouped by age and sex. The mean value for TC was $193.8 \pm 23.1$; $195.2 \pm 23.1$ for $M$ and $192.7 \pm 20.8$ for $F(p=$ 0.29 ). A previous study in an elderly population in Spain have reported mean concentrations of TC of $230.3 \pm 6.8 \mathrm{mg} / \mathrm{dl}$ for a non institutionalized population over 65 years (Gabriel et al., 2004). The TC values determined in this study were also slightly lower than the values reported in other national and international studies (Kafatos et al., 1991; Ettinger et al., 1992; Gómez Gerique et al., 1999). The TC level decreased $(p<0.001)$ with increasing age, in accordance with previous studies (Ferra et al., 1997), although significant differences between sex were not detected. Global prevalence of hypercholesterolemia (TC $>200$ $\mathrm{mg} / \mathrm{dl}$ ) was $8.7 \% ; 7.9 \%$ in the $\mathrm{F}$ group and slightly higher $9.9 \%$ in $\mathrm{M}$. Only $5 \%$ of the studied population had TC levels over $250 \mathrm{mg} / \mathrm{dl}$ ( $3 \%$ of $\mathrm{F}$ and $6.4 \%$ of $\mathrm{M}$ ). There are few studies on the prevalence of hypercholesterolemia in the elderly population of Spain. The Epicardian Study (Gabriel et al., 2004) reported a prevalence of $68.9 \%$ of hypercholesterolemia, which is eight times higher than the values reported in this study. Our values are also below the data reported by the Who-Erica project for the south of Europe (50\%) (Erica Research Group, 1998). Hypercholesterolemia is a risk factor for coronary heart disease for 60 to 70 years old people (Weverling-Rijnsburger et al., 1997). Lower cholesterol levels in the oldest population could be attributed to a selection of the 
Table 3

Mean values and standard deviation for serum lipids and blood pressure by age group

\begin{tabular}{|c|c|c|c|c|c|c|c|c|}
\hline \multirow{2}{*}{ Variable } & \multicolumn{6}{|l|}{ Age Group } & \multirow{2}{*}{ All Groups } & \multirow{2}{*}{$P$} \\
\hline & 1 & 2 & 3 & 4 & 5 & 6 & & \\
\hline TC & $199.4 \pm 25.6^{a}$ & $196.9 \pm 26.5^{a, c}$ & $188.1 \pm 10.1^{b, c}$ & $189.0 \pm 22.0^{a, b, c}$ & $180.0 \pm 12.0^{b}$ & $179.0 \pm 7.7^{a, b, c}$ & $193.8 \pm 23.1$ & 0.00 \\
\hline TC/HDLC & $3.6 \pm 1.3^{\mathrm{a}}$ & $3.5 \pm 1.3^{\mathrm{a}, \mathrm{b}}$ & $3.0 \pm 0.3^{\mathrm{b}}$ & $3.2 \pm 1.1^{a, b}$ & $2.8 \pm 0.4^{\mathrm{b}}$ & $2.7 \pm 0.2^{\mathrm{a}, \mathrm{b}}$ & $3.3 \pm 1.1$ & 0.00 \\
\hline HDLc & $57.8 \pm 8.4^{\mathrm{a}}$ & $59.7 \pm 8.1^{\mathrm{a}, \mathrm{b}}$ & $62.2 \pm 4.2^{\mathrm{b}, \mathrm{c}}$ & $62.5 \pm 7.5^{\mathrm{b}, \mathrm{c}}$ & $64.6 \pm 3.9^{c}$ & $66.4 \pm 2.1^{\mathrm{b}, \mathrm{c}}$ & $60.3 \pm 7.6$ & 0.00 \\
\hline LDLC & $134.8 \pm 33.5^{\mathrm{a}}$ & $131.0 \pm 34.2^{a, b}$ & $119.7 \pm 12.5^{b}$ & $120.2 \pm 28.8^{b}$ & $113.1 \pm 21.8^{b}$ & $105.1 \pm 10.8^{a, b}$ & $127.3 \pm 30.1$ & 0.00 \\
\hline $\mathrm{TG}$ & $143.1 \pm 17.1^{\mathrm{a}}$ & $139.1 \pm 17.3^{\mathrm{a}, \mathrm{c}}$ & $131.8 \pm 15.2^{\mathrm{b}, \mathrm{c}}$ & $135.6 \pm 22.6^{a, b}$ & $130.0 \pm 19.4^{b, c}$ & $118.1 \pm 14.9^{b}$ & $137.7 \pm 18.3$ & 0.00 \\
\hline SBP & $149.2 \pm 14.1^{\mathrm{a}}$ & $150.9 \pm 13.1^{\mathrm{a}}$ & $145.5 \pm 12.6^{a, b}$ & $141.8 \pm 12.3^{b}$ & $148.3 \pm 13.3^{\mathrm{a}, \mathrm{b}}$ & $145.1 \pm 9.1^{a, b}$ & $148.0 \pm 13.5$ & 0.00 \\
\hline DBP & $77.1 \pm 7.1^{\mathrm{a}}$ & $75.9 \pm 6.4^{\mathrm{a}}$ & $78.3 \pm 5.4^{\mathrm{a}}$ & $77.3 \pm 5.3^{\mathrm{a}}$ & $78.1 \pm 4.9^{\mathrm{a}}$ & $79.9 \pm 4.9^{\mathrm{a}}$ & $77.1 \pm 6.3$ & 0.11 \\
\hline
\end{tabular}

Different superscripts in the same row indicate significant differences $(p<0.05)$; TC: Total Cholesterol; HDLc: High Density Lipoprotein Cholesterol; LDLC: Low Density Lipoprotein Cholesterol; TG: Triglyceride; SBP: Systolic Blood Pressure; DBP: Diastolic Blood Pressure.

population due to the premature death of hypercholesterolemic individuals, since subjects with dyslipidemia rarely reach extreme old age (Galloto et al., 2008). However the importance of hypercholesterolemia as a risk factor for cardiovascular disease over 70 years' old people is controversial. In the very elderly there is evidence to suggest that high total cholesterol is associated with longevity (Weverling-Rijnsburger et al., 1997). At this age, it has been reported that HDLc and the ratio TC/HDLc are better predictive risk factors for isquemic CVD than TC or LDLc (Corti et al., 1995; Weverling-Rijnsburger, 2003)

The mean HDLc concentration was $60.3 \pm 7.6$ $\mathrm{mg} / \mathrm{dl}$, with higher values for the female group (60.5 $\pm 7.2)$ than for the male group $(58 \pm 8.0)(p=0.49)$ and with a significant increasing trend with age $(p<$ $0.05)$. This is consistent with data reported in the Cardiovascular Health Study (Ettinger et al., 1992). The mean values are higher than those reported for the Spanish elderly population $(48.2 \pm 15 \mathrm{mg} / \mathrm{dl})$ (Gabriel et al., 2004). Hipoalfalipoproteinemia (HDLc $<35 \mathrm{mg} / \mathrm{dl}$ ) was observed only in $1.5 \%$ of the population, a value which is under the $14 \%$ reported for the Spanish elderly population in the Epicardian Study. Regarding HDLc there is wide scientific evidence which suggests that it plays a protective role in the development of coronary heart disease, especially, in the elderly (Gotto, 1994; Ginsberg, 1994). Each 1\% increase in HDL-c has been associated with a $2-4 \%$ decrease in coronary heart disease risk. Low levels of HDLc have shown to be a powerful predictor of coronary heart disease and stroke in human prospective studies, even for those with normal levels of total cholesterol, which underline the relevance of the ratio TC/HDLc for the evaluation of blood lipids. The mean values for TC/HDLc for the studied population was $3.3 \pm 1.1$ $\mathrm{mg} / \mathrm{dl}$ for female and $3.4 \pm 1.2 \mathrm{mg} / \mathrm{d}$ for male $(\mathrm{p}=$ 0.35). $5.7 \%$ of the female and $8.1 \%$ of the male presented values were over 5 , which is the limit to be considered as cardiovascular risk. Reported mean values for other elderly national and international population (Ettinger et al., 1992; Gabriel et al., 2004) are over 4. In this sense, we can assume that the population in this study showed a low risk of cardiovascular disease.

The mean concentrations of LDLc were $127.3 \pm$ $30.1 \mathrm{mg} / \mathrm{dl} ; 129.0 \pm 32.9 \mathrm{mg} / \mathrm{d}$ for $\mathrm{M}$ and slightly lower for $F 126.0 \pm 27.8 \mathrm{mg} / \mathrm{dl}(p=0.33)$. These values are lower than those reported in other national survey for the same age group (159 \pm 37 $\mathrm{mg} / \mathrm{dl}$ ) and similar to the Cardiovascular Health Study (Ettinger et al., 1992). However, in contrast

Table 4

Mean values and standard deviation for serum lipids and blood pressure by group age and sex.

\begin{tabular}{|c|c|c|c|c|c|c|c|c|}
\hline \multirow{2}{*}{ Variable } & \multirow{2}{*}{ Sex } & \multicolumn{6}{|c|}{ Age Group } & \multirow{2}{*}{ All groups } \\
\hline & & 1 & 2 & 3 & 4 & 5 & 6 & \\
\hline \multirow{2}{*}{ TC } & $M$ & $198.5 \pm 24.0$ & $202.6 \pm 33.8$ & $187.3 \pm 10.2$ & $189.1 \pm 24.4$ & $179.6 \pm 14.4$ & $174.0 \pm 5.7$ & $195.2 \pm 25.7$ \\
\hline & $\mathrm{F}$ & $200.1 \pm 27.0$ & $192.4 \pm 18.2$ & $188.7 \pm 10.1$ & $188.9 \pm 20.3$ & $180.3 \pm 11.0$ & $181.0 \pm 8.0$ & $192.7 \pm 20.8$ \\
\hline \multirow{2}{*}{ TC/HDLC } & $M$ & $3.6 \pm 1.3$ & $3.7 \pm 1.6$ & $3.0 \pm 0.4$ & $3.1 \pm 1.1$ & $2.8 \pm 0.4$ & $2.6 \pm 0.1$ & $3.4 \pm 1.2$ \\
\hline & $\mathrm{F}$ & $3.7 \pm 1.4$ & $3.3 \pm 0.9$ & $3.1 \pm 0.3$ & $3.2 \pm 1.2$ & $2.8 \pm 0.3$ & $2.7 \pm 0.2$ & $3.3 \pm 1.1$ \\
\hline \multirow{2}{*}{ HDLc } & $M$ & $58.0 \pm 8.1$ & $58.4 \pm 9.6$ & $62.8 \pm 4.4$ & $62.9 \pm 7.4$ & $64.4 \pm 4.7$ & $66.5 \pm 3.5$ & $60.0 \pm 8.0$ \\
\hline & $\mathrm{F}$ & $57.7 \pm 8.7$ & $60.8 \pm 6.6$ & $61.7 \pm 4.0$ & $62.2 \pm 7.6$ & $64.7 \pm 3.6$ & $66.4 \pm 1.9$ & $60.5 \pm 7.2$ \\
\hline \multirow{2}{*}{ LDLc } & M & $134.2 \pm 31.1$ & $138.1 \pm 42.8$ & $118.3 \pm 12.4$ & $120.0 \pm 31.4$ & $109.4 \pm 16.1$ & $100.5 \pm 7.8$ & $129 \pm 32.9$ \\
\hline & $\mathrm{F}$ & $135.3 \pm 35.5$ & $125.5 \pm 24.8$ & $120.7 \pm 12.5$ & $120.3 \pm 27.2$ & $115.1 \pm 24.7$ & $107.0 \pm 12.0$ & $126.0 \pm 27.8$ \\
\hline \multirow{2}{*}{ TG } & $M$ & $145.0 \pm 17.5$ & $138.2 \pm 19.8$ & $136.2 \pm 19.7$ & $135.8 \pm 19.1$ & $120.1 \pm 12.6$ & $114.0 \pm 15.6$ & $138.8 \pm 19.4$ \\
\hline & $\mathrm{F}$ & $141.5 \pm 16.7$ & $139.8 \pm 15.3$ & $128.9 \pm 10.4$ & $135.4 \pm 25.5$ & $135.5 \pm 20.7$ & $119.8 \pm 16.1$ & $136.9 \pm 17.4$ \\
\hline \multirow{2}{*}{ SBP } & $M$ & $148.5 \pm 14.9$ & $150.1 \pm 10.5$ & $147.9 \pm 14.4$ & $142.5 \pm 11.3$ & $152.8 \pm 16.3$ & $154.0 \pm 8.5$ & $148.41 \pm 13.4$ \\
\hline & $\mathrm{F}$ & $149.9 \pm 13.6$ & $151.4 \pm 14.8$ & $143.8 \pm 11.0$ & $141.2 \pm 13.2$ & $145.8 \pm 11.1$ & $141.6 \pm 7.2$ & $147.6 \pm 13.5$ \\
\hline \multirow{2}{*}{ DBP } & $\mathrm{M}$ & $77.8 \pm 7.09$ & $75.5 \pm 4.7$ & $78.2 \pm 6.1$ & $76.8 \pm 4.1$ & $79.3 \pm 5.1$ & $83.5 \pm 2.1$ & $77.3 \pm 6.0$ \\
\hline & $\mathrm{F}$ & $76.6 \pm 7.18$ & $76.1 \pm 7.5$ & $78.3 \pm 4.9$ & $77.7 \pm 6.1$ & $77.4 \pm 4.9$ & $78.4 \pm 5.0$ & $77.1 \pm 6.6$ \\
\hline
\end{tabular}

TC: Total Cholesterol; HDLc: High Density Lipoprotein Cholesterol; LDLc: Low Density Lipoprotein Cholesterol; TG: Triglyceride; SBP: Systolic Blood Pressure; DBP: Diastolic Blood Pressure. 
with our findings, in both studies LDLc values were higher in woman than in men. Concentrations of LDLc decreased with increasing age $(p<0.05)$, in accordance with previous studies (Ettinger et al., 1992; Gabriel et al., 2004). Global prevalence o cardiovascular risk (LDLc $>160 \mathrm{mg} / \mathrm{dl}$ ) was found in $10.7 \%$ of the studied population while $26.4 \%$ was at moderate risk $(159 \mathrm{mg} / \mathrm{dl}<\mathrm{LDLc}>130 \mathrm{mg} / \mathrm{dl})$.

Mean TG levels were $137.7 \pm 18.8 ; 136 \pm 17.4$ for the $\mathrm{F}$ group and slightly lower for M group $138.8 \pm$ $19.4(p=0.30)$. These values are slightly lower than those reported in the Cardiovascular Health Study $(140 \pm 75 \mathrm{mg} / \mathrm{dl}$ for $\mathrm{M}$ and $139 \pm 69 \mathrm{mg} / \mathrm{dl}$ for $\mathrm{F})$ (Ettinger et al., 1992) but higher than values reported for other national studies in the elderly population (Gabriel et al., 2004; Lasheras-Mayo et al., 1999). TG concentrations were lower with increasing age ( $p<$ 0.0001 ). Hypertrigliceridemia (TG $>200 \mathrm{mg} / \mathrm{dl}$ ) was found only in $0.5 \%$ of the studied population. The National Cholesterol Education Program Adult Treatment Panel III (NCEP, 2001) suggests a cut point of $150 \mathrm{mg} / \mathrm{dl}$ for defining elevated levels of TG. In the present study $17.5 \%$ population was over this limit.

\subsection{Age, sex and blood pressure}

Mean SBP (Table 3 and 4) was $148.0 \pm 13.5$ (M $148.411 \pm 3.4$ and $F$ 147.62 \pm 13.5). Mean DBP was $77.1 \pm 6.3(\mathrm{M} 77.26 \pm 6.0$ and $\mathrm{F} 77.05 \pm 6.6)$. No significant differences were found between sexes. Hypertension (HTA) is a very common problem in older persons. The Framingham study showed that age is a risk factor for developing hypertension. The most common form of HTA in older persons is the isolated systolic hypertension (Kannel, 1996).

It has been reported that 35\% of the Spanish adults have HTA, while the percentage increase to
$40 \%$ in the middle ages and up to $60 \%$ in the elderly ( $<60$ year) (Banegas et al., 2006). In this study the prevalence of HTA was $71.6 \%$ (73\% of men and $70 \%$ of women) according to the criteria of ESHESC (2007). $30.8 \%$ of men and $25.3 \%$ of women had SBP $>130 \mathrm{mmHg}$. The Epicardian study stated that the prevalence of hypertension in the Spanish population over 65 years was 68\% (Gabriel Sánchez et al., 2004). Its is known that mean systolic and diastolic blood pressures rise with advancing age up to the sixth decade of life, whereupon systolic blood pressure continues to increase and diastolic pressure starts to decline (Fagard, 2002). We did not found this tendency in the studied group. Previous epidemiological studies have reported a positive correlation between hypercholesterolemia and other cardiovascular risk factors, as blood pressure (Banegas et al, 1993). We explored the correlations between SBP and serum lipids and we found a significant positive correlation $(p<0.05)$ with LDLc and TC and negative with HDLc.

\subsection{The Modified Mediterranean Diet Score (MMDS) and the relation with serum lipids}

Table 5 shows various descriptive characteristics of de Modified Mediterranean Diet Score (MMDS) as derived from its evaluation in the elderly people included in this study by sex and age. The mean dietary score was similar for men and women with a mean value of $30.7 \pm 2.8$ [30.8 \pm 2.5 for $F$ and 30.4 \pm 3.2 for $M(p=0.18)$ ], which represents $60.6 \% \pm$ 6.9 of adherence to the Mediterranean diet. In relation to the frequency of consumption of groups of foods, daily consumption was reported for olive oil by $80 \%$ of participants, non refine cereals by $89 \%$, legumes by $62 \%$ and fruits by $75 \%$ of participants.

Table 5

Descriptive characteristics of the Modified MediterraneanDiet Score (MMDS) in the Sierra de Huelva study

\begin{tabular}{|c|c|c|c|c|c|}
\hline Age group/sex & MMDS & sd & Variance & Maximum & Maximum \\
\hline 1 & 29.3 & 3.0 & 9.3 & 18.0 & 35.0 \\
\hline $\mathrm{F}$ & 29.7 & 2.7 & 7.1 & 23.5 & 34.5 \\
\hline $\mathrm{M}$ & 28.7 & 3.4 & 11.5 & 18.0 & 35.0 \\
\hline 2 & 31.3 & 2.3 & 5.3 & 24.0 & 37.0 \\
\hline $\mathrm{F}$ & 31.3 & 2.1 & 4.2 & 26.5 & 36.0 \\
\hline $\mathrm{M}$ & 31.3 & 2.6 & 6.8 & 24.0 & 37.0 \\
\hline 3 & 32.4 & 2.0 & 3.8 & 25.5 & 36.5 \\
\hline $\mathrm{F}$ & 32.3 & 2.1 & 4.6 & 25.5 & 35.5 \\
\hline $\mathrm{M}$ & 32.6 & 1.7 & 2.8 & 29.5 & 36.5 \\
\hline 4 & 29.8 & 2.4 & 5.8 & 22.0 & 34.5 \\
\hline $\mathrm{F}$ & 29.9 & 1.9 & 3.5 & 26.0 & 32.5 \\
\hline $\mathrm{M}$ & 29.8 & 3.0 & 9.0 & 22.0 & 34.5 \\
\hline 5 & 31.8 & 2.0 & 4.1 & 28.0 & 37.0 \\
\hline $\mathrm{F}$ & 31.6 & 2.1 & 4.2 & 28.0 & 37.0 \\
\hline $\mathrm{M}$ & 32.2 & 2.0 & 4.0 & 29.0 & 34.5 \\
\hline 6 & 29.4 & 3.0 & 9.3 & 26.0 & 33.5 \\
\hline $\mathrm{F}$ & 30.1 & 3.2 & 10.4 & 26.0 & 33.5 \\
\hline $\mathrm{M}$ & 27.8 & 2.5 & 6.1 & 26.0 & 29.5 \\
\hline All Groups & 30.7 & 2.8 & 7.9 & 18.0 & 37.0 \\
\hline
\end{tabular}


Daily consumption of vegetables was reported by $32 \%$ and $60 \%$ reported consumption $4-6 /$ week. In relation to rich protein-food groups, fish was consumed only once a week by $87 \%$ of participant, while lamb meat was reported to be consumed 2$3 /$ week by $48 \%$, and once a week by $39 \%, 81 \%$ reported to eat poultry once a week. It is relevant that $78 \%$ of the participants reported a high pigmeat and derived products consumption of 46/week. We explored the correlation between serum lipids and the different food groups. Pig meat consumption was negatively correlated with TC and LDLc, and positively with HDLc. Egg consumption was positively correlated with TC, LDLC and TC/HDLC and negatively with HDLC and TG.

It has been suggested that the overall dietary patterns and not single nutrients should be studied, since food items might have a synergistic and antagonistic effect on health. In order to find the association between the dietary pattern and the serum lipid profile we explore the correlation between the MMDS and lipid levels. We found significant $(p<0.05)$ negative correlation between the MMDS and TG, which indicate that higher adherence to the Mediterranean diet, as evaluated by the MMDS, are related to lower TG levels.

\section{CONCLUSIONS}

Taking into account the serum lipid profile of the studied population in comparison with data from other Spanish populations, we can state a lower risk of CVD as well as a higher life expectancy. The population showed a high adherence to the Mediterranean diet. Further studies are needed to establish the influence of local Iberian pig meat products consumption and life style on CVD risk factors.

\section{ACKNOWLEDGMENTS}

We are acknowledged to the elderly people that have collaborated in this study.

\section{REFERENCES}

Bertomeu V, Castillo-Castillo J. 2008. Situación de la enfermedad cardiovascular en España. Del riesgo a la enfermedad. Rev. Esp. Cardiol. 8, 2-9.

Banegas JR, Villar F, Pérez C, Jiménez R, Gil E, Muñiz J, Juane R. 1993. Estudio epidemiológico de los factores de riesgo cardiovascular en la población española de 35 a 64 años. Rev. San. Hig. Pub. 67, 419-445.

Banegas JR, Villar F, Graciani A, Rodríguez-Artalejo F. 2006. Epidemiología de las enfermedades cardiovasculares en España. Rev. Esp. Cardiol. Supl. 6, G3-12.

Contaldo F, Pasanisi F, Mancini M. 2003. Beyond the traditional interpretation of Mediterranean diet. Nutr. Metab. Cardiovasc. Dis. 13, 117-119.

Corti MC, Guralnik JM, Salive ME, Harris T, Field TS, Wallace RB, Berkman LF, Seeman TE, Glynn RJ,
Hennekens CH, Havlik RJ 1995. HDL cholesterol predicts coronary heart disease mortality in older persons. JAMA 274, 539-44.

De Lorgeril M, Salen P, Martin J, Monjaud I, Delaye J, Mamelle N. 1999. Mediterranean diet, traditional risk factors and the rate of cardiovascular complications after myocardial infarction: final report of the Lyon diet heart study. Circulation 99, 799-85.

Erica Research Group. 1988. The CHD risk map of Europe. The first Report of the WHO-ERICA Project. Eur. Heart. J. 9, S1-S26.

Ettinger WH, Wahl PW, Kuller LH, Bush TI, Tracy RP, Manolio TA, Borhani NO, D, Oleary DH, Furberg CD, Bond ME, Heiss G, Klopfenstein S, Lyles M, Mittelmark M, Tell GS, Toole JF Cody M, Garner G, Cruise G, Robbins J, Bommer W, Lee M, Schenker MB Tupper Cl Himmelmann T, Labaw F, Kay J, Borhani P, Fried LP,Comstock GW German PS, Kittner SJ, Kumanyika S, Price TR, Rock RC, Bryan RN, Szklo M, Tabatznik B, Tockman MS, Hill J, Chabot JB, Cauley J, Matthews K, Newman A, Orchard TJ, Rutan GH, Schulz R, Smith VE, Wolfson SK, Meyer P, Mclaughlin B, Gardin JM, Antonculver H, Henry WL, Lobodzinski S, Whittenberger J, Knoll P, Conner J, Polak JF, Potter J, Bovill E, Cornell E, Enright P, Toogood S, Rautaharju P, Rautaharju F, Kronmal RA, Psaty BM, Siscovick D, Hermanson B, Savage PJ, Smith P.1992. Lipoprotein lipids in older people. Results from the Cardiovascular Health Study. Circulation 86, 858-69.

National Cholesterol Education Program (NCEP) Expert Panel on Detection, Evaluation, and Treatment of High Blood Cholesterol in Adults. Executive Summary of the Third Report. 2001. JAMA 285, 2486-2497.

Fagard RH. 2002 Epidemiology of hypertension in the elderly. Am J Geriatr Cardiol 11, 23-28.

Ferra, A, Barret-Conner, E. Shan, J. 1997. Total, LDL and HDL cholesterol decrease with age in older men and women. Circulation 96, 37-43.

Galloto A, Dominguez LJ, Pineo A, Ferlisi A, Putignano E, Belvedere M, Costanza G, Barbagallo M. 2008. Cardiovascular risk factors in centenarians. Exp. Gerontol. 43, 106-113.

Gabriel R, Saiz C, Susi R, Alonso M, Vega S, Lopez I, Cardenal MMC, Gomez-Gerique JA, Muniz APYJ. 2004. Epidemiology of lipid profile of the Spanish elderly population: the Epicardian study. Med. Clin. 122, 605-609.

Gabriel Sánchez R, Novella Arribas B, Alonso Arroyo M, Vega Quiroga S, López García I, Suárez Fernández C, Muñiz García J. 2004 . El proyecto Epicardian: un estudio de cohortes sobre enfermedades y factores de riesgo cardiovasculares en ancianos españoles: consideraciones metodológicas y principales hallazgos demográficos. Rev. Esp. Salud Publica 78 (2) 243-255.

García Rebollo AJ, Maciá Botejara E, Ortiz Cansado A, Morales, PJ, Martín Bellido M, Fallola Sánchez A, Mena Arias P, Campillo Alvarez JE.1998. Effects of consumption of meat product rich in monounsaturated fatty acids (the ham from the Iberian pig) on plasma lipids. Nutr. Res. 18, 743-750.

Ginsberg HN. 1994. Lipoprotein metabolism and its relationship to atherosclerosis. Med. Clin. North. Am. 78, 1-20.

Gómez Gerique JA, Gutiérrez-Fuentes JA, Montoya MT, Porres A, Rueda A, Avellaneda A, Rubio MA. 1999. Estudio del perfil lipídico de la población española: 
estudio DRECE. Dieta y riesgo de enfermedades cardiovasculares en España. Med. Clin. 113, 730-5

Gotto AM Jr. 1994. Lipid and lipoprotein disorders in Pearson TA, Criqui MH, Luepker RV, Oberman A, Wilson M (Ed.). Primer in Preventive Cardiology. American Heart Association, Dallas, pp 107-129.

Instituto Nacional de Estadítica, 2007. En http://www.ine. es/prensa/np472.pdf (consultada 22 Enero 2009).

Kafatos A, Schlienger JL, Deslypere JP, Ferro-Luzzi A, Amorim-Cruz JA. 1991. Euronut-SENECA study on Nutrition and the elderly. Nutrition status: serum lipids. Eur. J. Clin. Nutr. 45, 53-61.

Kannel WB. 1996. Blood pressure as a cardiovascular risk factor. JAMA 275, 1571-1576.

Keys A. 1980. Seven countries: a multivariate analysis of death and coronary heart disease. Cambridge, MA. Harvard University Press.

Lairon D. 2007. Intervention studies on Mediterranean diet and cardiovascular risk. Mol. Nutr. Food. Res. 51, 1209-1214.

Lasheras-Mayo C, González González C, Aparicio MJ, Menéndez Patterson A., Fernández Fernández. 1999. Factores de riesgo cardiovascular en una muestra de ancianos institucionalizados y de la comunidad. Rev. Mult. Gerontol. 9, 129-138

Mayoral P, Martínez-Salgado CS, Santiago JM, Rodríguez-Hernández MV, García-Gómez ML, Morales A, López-Novoa JM, Macias-Núñez JF. 2003. Effect of ham protein substitution on oxidative stress in older adults. Nutr. Health Aging. 7, 84-89.

Mead A, Atkinson G, Albin D, Alphey D, Baic S, Boyd O, Cadigan L , Clutton L, Craig L), Flanagan C), Greene P, Griffiths E, Lee NJ, Li M, McKechnie L, Ottaway J, Paterson K, Perrin L, Rigby P, Stone D, Vine R, Whitehead J, Wray L, Hooper L 2006. Dietetic guidelines on food and nutrition in the secondary prevention of cardiovascular disease - evidence from systematic reviews of randomized controlled trials. J. Hum. Nutr. Diet. 19, 401-419.

Panagiotakos DB, Pitsavos C Stefanadis C. 2006. Diary patterns: A Mediterranean diet score and its relation to clinical and biological markers of cardiovascular disease risk. Nutr. Metab. Cardiovasc. Dis. 16, 559-568.

Sofi F, Cesari F, Abbate R, Gensini GF, Casini A. 2008. Adherence to Mediterranean diet and health status: meta-analysis. BMJ 337, al 344.

Sociedad Española de Arteriosclerosis. 1994. Dieta y enfermedades cardiovasculares: recomendaciones de la Sociedad Española de Arteriosclerosis. Clin. Invest. Arterioscl. 6, 43-61.

The Task Force for the Management of Arterial Hypertension of the European Society of Hypertension (ESH) and of the European Society of Cardiology (ESC). 2007. 2007-Guidelines for the Management of Arterial Hypertension. Blood Pressure 16, 135-232.

Tinker A. 2002. The social implications of an ageing population. Mech. Ageing Dev. 123, 729-735.

Trichopoulou A, Corella D, Martinez-Gonzalez MA, Soriguer F, Ordovas JM. 2006. The Mediterranean diet and cardiovascular epidemiology. Nutr. Rev. 64, S13-S19 Part 2.

Trichopoulou A, Lagiou P. 1997. Healthy traditional Mediterranean diet: An expression of culture, history, and lifestyle. Nutr. Rev. 55, 383-389.

Viera Alcaide, Isabel. 2007. Estudio de la influencia del régimen de vida en la composición de acidos grasos, triglicéridos e hidrocarburos de la grasa subcutánea del cerdo iberico. Ph D. Diss. Seville University.

Villar Álvarez F, Banegas Banegas JR, De Mata Donado Campos J, Rodríguez Artalejo F. 2007. Mortalidad y morbilidad cardiovascular por enfermedades del sistema circulatorio in Sociedad Española de Arteriosclerosis (Ed). Las enfermedades cardiovasculares en España: hechos y cifras. Informe SEA 2007. Visto Bueno Equipo Creativo SL, España, pp 21-35

Weverling-Rijnsburger AWE, Jonkers IJAM, Van Exel E, Gussekloo J, Westendorp RGJ. 2003. High-density vs low-density lipoprotein cholesterol as the risk factor for coronary artery disease and stroke in old age. Arch. Intern. Med. 163, 1549-54.

Weverling-Rijnsburger AWE, Blauw, GJ., Lagaay AM, Knook, DL., Meinders AE., Westendorp, RGJ. 1997. Total cholesterol and the risk of mortality in the oldest old. Lancet 350, 1119-1123.

Willett WC. 2006. The Mediterranean diet: science and practice. Public. Health Nutr. 9, 105-110.

Willett WC, Sacks F, Trichopoulou A, Drescher G, FerroLuzzi A, Helsing E, Trichopoulos D. 1995. Mediterranean diet pyramid: a cultural model for healthy eating. Am. J. Clin. Nutr. 61, 1402-1406. 